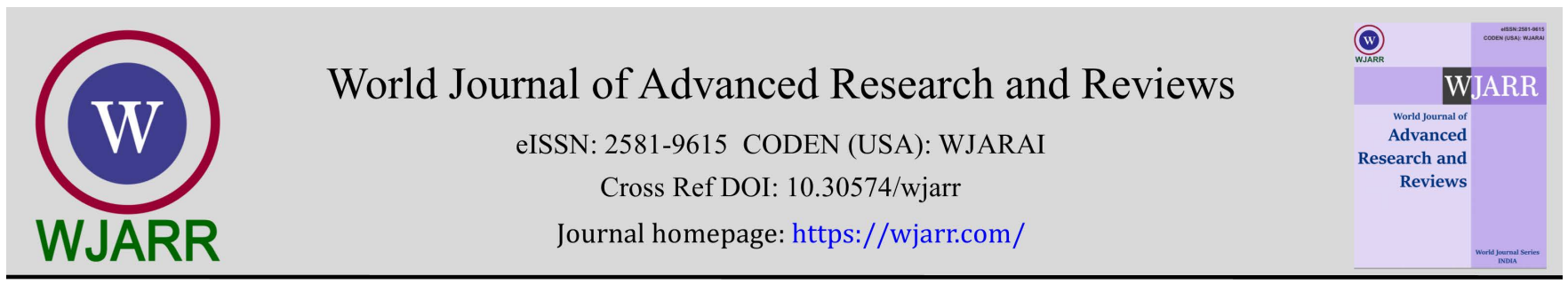

(RESEARCH ARTiClE)

Check for updates

\title{
Production of gluconic acid by fungal species isolated from soil in Keffi, Nigeria
}

\author{
Makwin Danladi Makut*, Chioma Deborah Nzeduru, Ike Kenneth Ekeleme, Jibril Egwu Owuna and Obuneme \\ Smart Obiekezeie
}

Department of Microbiology, Nasarawa State University, P.M.B 1022, Keffi, Nigeria.

World Journal of Advanced Research and Reviews, 2021, 11(03), 382-390

Publication history: Received on 19 August 2021; revised on 21 September 2021; accepted on 23 September 2021

Article DOI: https://doi.org/10.30574/wjarr.2021.11.3.0465

\begin{abstract}
This investigation aimed at production of gluconic acid by fungal species isolated from soil in Keffi. Standard microbiological methods were employed for isolation and identification of the fungal isolates. The yields of gluconic acid produced by the different isolates of the fungi were determined using gas chromatograph and mass Spectrometry. The occurrence of fungi showed that Rhizopus oryzae was $100 \%$, Aspergillus carneus was $75.0 \%$, Aspergillus niger was $75.0 \%$ and Aspergillus terreus was $100 \%$ while Trichoderma viride was $25.0 \%$ and Fusarium moniliforme was $25.0 \%$. The result further demonstrated that three species of the fungal isolates Aspergillus niger, Aspergillus carneus and Fusarium moniliforme were found to produce gluconic acid. Screening for gluconic acid production showed that Aspergillus carneus isolated from locations As1, Cs1 and Cs2, Aspergillus niger isolated from locations Bs1, Bs2 and Cs4 were able to produce gluconic acid. Result of effect of temperature, $\mathrm{pH}$, substrate concentration and fermentation time on production of gluconic acid showed that Aspergillus niger Bs2 produced highest amount of gluconic acid at $28^{\circ} \mathrm{C}$, similarly highest amount for gluconic acid produced by Aspergillus carneus As1 was at $28^{\circ} \mathrm{C}$, whereas Fusarium moniliforme Bs4 produced highest at $30^{\circ} \mathrm{C}$. pH 6.5 was found to the best optima pH for production of both gluconic acid for the fungi studied namely Aspergillus niger Bs2 and Aspergillus carneus As 1 and Fusarium moniliforme Bs4 produced highest gluconic acid at $\mathrm{pH}$ 5.5. The substrate concentration showed highest production of gluconic acid was produced by Aspergillus niger Bs2 at substrate concentration of 25\%. Aspergillus carneus As1 produced highest at substrate concentration of $20 \%$ and Fusarium moniliforme Bs4 produced highest at substrate concentration of $20 \%$. The fermentation time showed highest production of gluconic acid by Aspergillus niger Bs2 and Aspergillus carneus As1 was after 144 hours whereas $F$. moniliforme Bs4 produced gluconic acid after $120 \mathrm{hrs}$ respectively. The fungi species isolated from soil in keffi revealed great ability in production of gluconic acid.
\end{abstract}

Keywords: Fungi; Gluconic acid; Temperature; pH; Substrate concentration and fermentation time

\section{Introduction}

Gluconic acid is an important organic acid resulting from the oxidation of D-glucose. The unique property of this acid such as low toxicity, low corrosively and complexing capability with metal ions has enabled it's wide application in the food, pharmaceutical, textile, leather and other industries Shindia, et al.[1]]. Thus, the high demand of this organic acid has been on increased for the Pass 20 years and production is growing to more than 60,000 tons every year and still on increase El-Enshasy [2]. Commercially, gluconic acid is produced by three different methods, chemical oxidation of glucose with a hypochlorite solution Kundu and Das [3], electrolytic oxidation of glucose solution containing a known value of bromide, and fermentation process where specific microorganisms are grown in medium containing glucose and other ingredients. The microbial fermentation process offers an attractive technique for the gluconic acid production to alleviate the problems related to chemical production such as the inevitable side reactions and also to further economize the bioprocess.

\footnotetext{
${ }^{*}$ Corresponding author: MD Makut

Department of Microbiology, Nasarawa State University, P.M.B 1022, Keffi, Nigeria.
}

Copyright (C) 2021 Author(s) retain the copyright of this article. This article is published under the terms of the Creative Commons Attribution Liscense 4.0. 
A wide group of microorganisms, particularly filamentous fungi have the ability for gluconic acid production Shindia, et al. [1]. The production of gluconic acid is mainly done in batch cultivation using several species belonging to the following fungal genera, Aspergillus, Penicillium, Fusarium, Mucor, and Gliocladium Lee et al. [4]. Among the different fungal genera, it has been reported that the accumulation of large amounts of the gluconic acid and its salts are restricted to certain species of Aspergillus, especially A. niger which considered as the most industrially important gluconic acid producer in fermentation industry Sankpal and Kullkarni [5]. Because of its industrial importance, many investigators have been worked for optimization as well as overproduction of gluconic acid by improving fungal producers Sankpal and Kulkarni [5] El-Enshasy [2]. Also, developing an alternative method in screening techniques to identify and develop possible native fungal strains for commercial exploitation of the process (Spankpal, et al [6], despite the abundant availability of commercial gluconic acid. The aim of this research is production of gluconic acid by fungal species isolated from soil in Keffi, Nigeria.

\section{Material and methods}

\subsection{Sample Collection}

Four soil samples were randomly collected (at the top soil) from four different locations of Keffi metropolis location A (high court), location B (Angwan lamnbu), location C (GRA) and location D (Old barracks), using a clean hand trowel and stored using disposable black polythene bags and transported immediately to the Microbiology Laboratory, Nasarawa State University, Keffi for analysis.

\subsection{Isolation of fungal strains}

The isolation of fungal was carried out following a method described by Makut and Ade-Ibijola [7]. One (1) gram of the soil sample was suspension in a test tube containing $9 \mathrm{ml}$ of sterile distilled water to make a soil suspension and tenfold serial dilution was made by transferring one $\mathrm{ml}$ of the soil suspension to another test tube containing $9 \mathrm{ml}$ of sterile distilled water. These steps were repeated ten times to obtain a dilution of $10^{-6}$. From each of the first three test tubes, $0.1 \mathrm{ml}$ of the aliquot was spread on Potato dextrose agar plates and was incubated at $26^{\circ} \mathrm{C}$ for 4 days.

\subsection{Identification of fungal species}

Identification of fungal species was carried out as described by Makut and Ade-Ibijola [7]. Identification was based on microbiological standard procedure using cultural and morphological characteristics. The cultural characteristics were determined by their appearance on culture plates while the morphological features were determined microscopically using lactophenol cotton blue staining technique. The isolates were identified with reference to the fungi standard chart atlas.

\subsection{Screening for gluconic acid Producing fungal strains}

Screening for gluconic acid Producing fungal strains were carried out as described by El-Enshasy, [8]. The medium used for preparation of calcium carbonate plates was consist of, glucose, 10g; (N H 4\ H PO , OA ; MgS04.7Hp, 0.2g; KHl04, $0.2 \mathrm{~g}$; CaCOo. SOg and agar $20 \mathrm{~g}$ dissolved in $20 \mathrm{ml}$ of double distilled water and autoclaved at $15 \mathrm{Ib}$ for $15 \mathrm{~min}$. CaCO, was sterilized separately and added to medium at the time of plating. The medium was inoculated by 10 -fold diluted spore suspension following incubation at $30^{\circ} \mathrm{C}$ for 3days. A clear zone was observed around distinct colonies on the plates indicating the production of calcium gluconate. The fungal producing clear zones were picked up and store for further use

\subsection{Preparation of Cassava baggers starch substrates}

The substrate was prepared using a method described by Ekeleme, et al. [9] with modification corn starch. Cassava baggers was collected and sun dry and grind into powder form using clean grinding machine and sieve. Five hundred gram $(500 \mathrm{~g})$ powder form was added into 4 liter of distilled water and sieves to form a homogenous mixture and placed at $4^{\circ} \mathrm{C}$ for $24 \mathrm{~h}$. The starch settled down was separated from liquid and oven dried at $60^{\circ} \mathrm{C}$, overnight. A starch solution of $20 \mathrm{~g} / \mathrm{l}$ was dissolve and autoclaved at $5.0 \mathrm{lbs} / \mathrm{in} 2$ pressure $\left(115^{\circ} \mathrm{C}\right)$ for $5 \mathrm{~min}$. To liquefy starch, alpha amylase $(2.0 \mu / \mathrm{ml})$ was added and heated at $95^{\circ} \mathrm{C}$ in a water bath for $15 \mathrm{~min}$. For saccharification, amyloglucosidase $(2.0 \mu / \mathrm{ml})$ was added and heated at $55^{\circ} \mathrm{C}$ while constant stirring for about $4 \mathrm{~h}$. 


\subsection{Production of gluconic acid}

\subsubsection{Preparation of inoculum for fermentation}

Preparation of inoculum for fermentation was carried out as described by Ekeleme et al. [10]. Five (5ml) of $0.3 \%$ sterile tween 80 containing in peptone water with some glass beads were transferred into four (4) days' slant culture of fungal species and was shake thoroughly until spores were dislodge and $10^{5}$ of the spores was transferred into peptone broth and incubated at $26^{\circ} \mathrm{C}$ for 12 hours.

\subsection{Media formulation and fermentation technique}

The batch fermentation was carried out as described by Ekeleme et al. [10] with modification, the modification was the use of Cassava baggers Starch hydrolysate. Cassava baggers Starch hydrolysate and nitrogen sources such as: M1 [glucose $(20 \mathrm{~g} / \mathrm{L})$, soya bean cake $(2.5 \mathrm{~g} / \mathrm{L}), \mathrm{NH}_{4} \mathrm{Cl} 0.4 \mathrm{~g}, \mathrm{KH}_{2} \mathrm{PO}_{4} 0.1 \mathrm{~g}, \mathrm{MgSO}_{4}, 7 \mathrm{H}_{2} \mathrm{O} 0.025 \mathrm{~g}$; and was taken in $250 \mathrm{ml}$ conical flasks. The flasks were plugged with cotton and autoclaved at 15 psi for 15 min. The sterilized flasks were inoculated with $5.0 \mathrm{ml}$ of the inoculum under aseptic conditions. Sterilized ferrocyanide (200 ppm free ions concentration) was added to each flask. The flasks were placed in an incubated at different temperature. All the experiments were run parallel in duplicates.

\subsection{Effect of $\mathrm{pH}$ on gluconic acid production}

The effect of pH was carried out following a method described by Ekeleme et al. [10]. Fifty (200) ml of the different fermentation substrate were transfer into different conical flasks. The pH ranges were adjusted to, 5.5, 6.0 and 6.5 of fermentation media. One (1) $\mathrm{N} \mathrm{HCl}$ was used in adjusting the $\mathrm{pH}$ of the media.

\subsection{Effect of temperature on gluconic acid production}

Effect of temperatures was carried out following a method described by Ekeleme et al. [9]. Fifty (50) ml of the different fermentation substrate were transfer into different conical flasks and the fermentation media was incubated at $28^{\circ} \mathrm{C}$ $39^{\circ} \mathrm{C}$.

\subsection{Effect of fermentation duration on gluconic acid production}

The effect of fermentation duration was carried out as described by Ekeleme et al. [9]. Different time interval were monitored during the fermentation of the media after 72 hours to 192 hours.

\subsection{Estimation of gluconic acid}

The gluconic acid produced during fermentation was determined by Gas Chromatography and Mass Spectrometry (GC and MS) Akalin et al., [11] as detailed below;

\subsection{Sample preparation}

During sample preparation, $7 \mathrm{~mL}$ of fermented media was added to $40 \mathrm{~mL}$ of buffer-acetonitrile mobile phase $(0.5 \%$ $(\mathrm{w} / \mathrm{v})(\mathrm{NH} 4) 2 \mathrm{HPO} 4(0.038 \mathrm{M})-0.4 \%(\mathrm{v} / \mathrm{v})$ acetonitrile $(0.049 \mathrm{M})$, at pH 2.24 with H3PO4), extracted for 1 hour in orbital shaker and centrifuged at $6000 \mathrm{xg}$ for $5 \mathrm{~min}$. The supernatant was collected and filtered once through filter paper Whattman No. 1 and twice through a $0.45 \mu \mathrm{m}$ membrane filter, and then used directly for GC and MS analysis. Duplicate analyses were performed on all samples.

\section{GC and MS Analysis}

Chromatograph equipped with flame-ionization detector. The column used for the separation of solvent was PEG (2.1m $\mathrm{x} 3.0 \mathrm{~mm})$. The operating conditions was mobile phase, aqueous $0.5 \%(\mathrm{w} / \mathrm{v})\left(\mathrm{NH}_{4}\right) 2 \mathrm{HPO}_{4}(0.038 \mathrm{M})-0.2 \%(\mathrm{v} / \mathrm{v})$ acetonitrile $(0.049 \mathrm{M})$ adjusted to $\mathrm{pH} 2.24$ with $\mathrm{H}_{3} \mathrm{PO}_{4}$; flow rate $0.3 \mathrm{~mL} \mathrm{~min}-1$; ambient column temperature. The mobile phase was prepared by dissolving analytical-grade $\left(\mathrm{NH}_{4}\right) 2 \mathrm{HPO}_{4}$ in distilled deionized water, GC and MS -grade acetonitrile, and $\mathrm{H}_{3} \mathrm{PO}_{4}$. GC and MS -grade reagents was used as standards (Sigma Chemical Co., St. Louis, MO). Solvents were filtered through a $0.45 \mu \mathrm{m}$ membrane filter and one hundred and twenty degrees centigrade $\left(120^{\circ} \mathrm{C}\right)$, Nitrogen gas $\left(30 \mathrm{~mL} /\right.$ minutes) was used as carrier gas. The temperatures of injector and detector were $150^{\circ} \mathrm{C}$ and $200^{\circ} \mathrm{C}$ respectively. The Peaks were recorded on "SHIMADZU C-R-4_A, Chromatograph", and was identified by comparison of the retention times with that of standard mixture. The experiment was carried out in duplicate and the means \pm standard deviations of the yield of gluconic acid were recorded. 


\subsection{Statistical Analyses}

Statistical analyses of data were carried out as described by Si et al. [12]. All experiments were conducted in duplicates. Unless otherwise indicated, for each experiment undertaken, the mean levels of variables and the standard deviations (SD) were calculated. Comparisons of variables were made with the One-Way Analysis of Variance (ANOVA). A value of $\mathrm{p}<0.05$ was considered statistically significant. Statistical analyses were conducted using the software programmer, Statistical Package for Social Sciences (SPSS 21.0; IBM, USA).

\section{Results and discussion}

The cultural morphological characteristics of the fungal isolated from soil in Keffi as showed in Table1.

Table 4.2 shows the percentage occurrence of different fungal species isolated from different soil location in Keffi. The percentage occurrence fungal isolates showed that Rhizopus oryzae have 100\% occurrence from all the location and 2 were isolated from location A, 1 each were isolated from location B and D respectively. Aspergillus carneus have $75.0 \%$ occurrence from all the location and 1 was isolated from location A and 2 were isolated from location C. Aspergillus niger have $75.0 \%$ occurrence from all the location and 2 were isolated from location B and 1 from location C. Aspergillus terreus have $100 \%$ occurrence from all the locations and 1 each were isolated from all the locations A-D. Trichoderma viride have $25.0 \%$ occurrences and 1 each was isolated from location A and 1 from location D. Lastly Fusarium moniliforme have $25.0 \%$ occurrences and 1 each was isolated from location B and 1 from location D respectively.

The screening for the ability of gluconic acid production by the fungal isolates is as given Table 3 . The different species of the fungal showed ability of gluconic acid production were Aspergillus carneus As1, Aspergillus carneus, Aspergillus carneus Cs2, Aspergillus niger Bs1, Aspergillus niger Bs2 and Aspergillus niger Cs4 were gluconic acid producers. Fusarium moniliforme Bs4 Fusarium moniliforme Ds1 also, produced gluconic acid whereas Rhizopus oryzae, Aspergillus terreus and Trichoderma viridei isolates did not have the ability to produced gluconic acid as observed in this study.

\subsection{Different effects of fermentation parameters on gluconic acid production}

The Effect of temperature on gluconic acid production by fungal isolated is as shown in Figure 1. Aspergillus niger Bs2 produced high gluconic acid at temperature of $28^{\circ} \mathrm{C}(8.04 \mu \mathrm{g} / \mathrm{ml})$ followed by at $30^{\circ} \mathrm{C}(7.35 \mu \mathrm{g} / \mathrm{ml})$, at $33^{\circ} \mathrm{C}(6.99 \mu \mathrm{g} / \mathrm{ml})$, at $36^{\circ} \mathrm{C}(5.82 \mu \mathrm{g} / \mathrm{ml})$ and at $39^{\circ} \mathrm{C}(4.75 \mu \mathrm{g} / \mathrm{ml})$. Similarly, Aspergillus carneus As 1 produced highest gluconic acid at $28^{\circ} \mathrm{C}$ $(7.34 \mu \mathrm{g} / \mathrm{ml})$ followed by $(7.05 \mu \mathrm{g} / \mathrm{ml})$ at $30^{\circ} \mathrm{C},(5.42 \mu \mathrm{g} / \mathrm{ml})$ at $33^{\circ} \mathrm{C},(4.81 \mu \mathrm{g} / \mathrm{ml})$ at $36^{\circ} \mathrm{C}$ and $(3.12 \mu \mathrm{g} / \mathrm{ml})$ at $39{ }^{\circ} \mathrm{C}$. Fusarium moniliforme Bs4 produced high gluconic acid at $30^{\circ} \mathrm{C}(5.03 \mu \mathrm{g} / \mathrm{ml})$ followed by at $33^{\circ} \mathrm{C}(4.23 \mu \mathrm{g} / \mathrm{ml})$ of gluconic acid, at $36^{\circ} \mathrm{C}(4.01 \mu \mathrm{g} / \mathrm{ml})$, at $28^{\circ} \mathrm{C}(3.55 \mu \mathrm{g} / \mathrm{ml})$ and at $39^{\circ} \mathrm{C}(2.92 \mu \mathrm{g} / \mathrm{ml})$ of gluconic acid respectively.

Table 1 Cultural and Morphological characteristics of Fungal isolated

\begin{tabular}{|c|c|c|}
\hline \multicolumn{3}{|c|}{ Characteristics } \\
\hline Cultural & Morphological & Fungal \\
\hline $\begin{array}{l}\text { Grow fast with white cotton like at first later } \\
\text { becoming brownish grey to blackish-grey }\end{array}$ & $\begin{array}{l}\text { Sporangia are greyish-black, spherical and } \\
\text { Sporangiospores are angular to broadly } \\
\text { ellipsoidal }\end{array}$ & $\begin{array}{l}\text { Rhizopus } \\
\text { oryzae }\end{array}$ \\
\hline $\begin{array}{l}\text { Colonies are typically black in colour with white } \\
\text { cleistothecia developing within and upon the } \\
\text { conidial layer. Reverse is olive and brown }\end{array}$ & $\begin{array}{l}\text { Branched conidiophores with chains of } \\
\text { conidia like a brush }\end{array}$ & $\begin{array}{l}\text { Aspergillus } \\
\text { carneus }\end{array}$ \\
\hline $\begin{array}{l}\text { colonies consist of } \quad \text { a compact } \\
\text { white or yellow basal felt covered by a dense layer } \\
\text { of dark-brown to black }\end{array}$ & $\begin{array}{l}\text { conidial heads are biseriate, large, globose, } \\
\text { dark brown, becoming radiate with the } \\
\text { phialides borne on metulae }\end{array}$ & $\begin{array}{l}\text { Aspergillus } \\
\text { niger }\end{array}$ \\
\hline $\begin{array}{l}\text { Colony appear as sand-brown in colour with a } \\
\text { yellow to deep dirty brown reverse of plate }\end{array}$ & $\begin{array}{l}\text { Conidiophore stipeses are hyaline and } \\
\text { smooth-walled. conidia are conidial heads are } \\
\text { biseriate }\end{array}$ & $\begin{array}{l}\text { Aspergillus } \\
\text { terreus }\end{array}$ \\
\hline $\begin{array}{l}\text { First grow white and downy, later developing } \\
\text { yellowish-green to deep green compact tufts, } \\
\text { often only in small areas or in concentric ring-like } \\
\text { zones on the agar surface }\end{array}$ & $\begin{array}{l}\text { Conidiophores are branched, irregularly } \\
\text { verticillate, bearing clusters of divergent, } \\
\text { often irregularly bent, flask-shaped phialides }\end{array}$ & $\begin{array}{l}\text { Trichoderma } \\
\text { viride }\end{array}$ \\
\hline
\end{tabular}


Colonies are usually fast growing, pale or bright coloured (depending on the species) with a cottony aerial mycelium. The colour of the thallus are red or purple shades
Produce both macro- and microconidia from slender phialides. Macroconidia are hyaline several-celled, fusiform to sickle-shaped
Fusarium moniliforme

Figure 2 shows the effect of $\mathrm{pH}$ on gluconic acid production by fungal isolates. The various amounts of gluconic acid produced showed that Aspergillus niger Bs2 produced highest gluconic acid at pH $6.5(7.09 \mu \mathrm{g} / \mathrm{ml})$ followed by at $\mathrm{pH}$ $6.0(6.89 \mu \mathrm{g} / \mathrm{ml}),(5.12 \mu \mathrm{g} / \mathrm{ml})$ at $\mathrm{pH} 5.5,(4.19 \mu \mathrm{g} / \mathrm{ml})$ at $\mathrm{pH} 5.0$, at $\mathrm{pH} 4.5(4.18 \mu \mathrm{g} / \mathrm{ml})$ and at $\mathrm{pH} 4.0(3.12 \mu \mathrm{g} / \mathrm{ml})$. Similarly, Aspergillus carneus As1 produced highest gluconic acid at pH $6.5(6.51 \mu \mathrm{g} / \mathrm{ml})$ followed by at $\mathrm{pH} 6.0$ and $\mathrm{pH}$ $5.5(5.43 \mu \mathrm{g} / \mathrm{ml})$, at pH5.0 $(4.68 \mu \mathrm{g} / \mathrm{ml})$, at pH4.5 $(3.32 \mu \mathrm{g} / \mathrm{ml})$ and at $\mathrm{pH} 4.0$ produced the lowest $(3.21 \mu \mathrm{g} / \mathrm{ml})$ respectively. Fusarium moniliforme Bs4 produced highest gluconic acid at $\mathrm{pH} 5.5(4.03 \mu \mathrm{g} / \mathrm{ml})$ followed by at $\mathrm{pH} 6.0$ $(4.00 \mu \mathrm{g} / \mathrm{ml}),(3.87 \mu \mathrm{g} / \mathrm{ml})$ at $\mathrm{pH} 6.5,(3.12 \mu \mathrm{g} / \mathrm{ml})$ at $\mathrm{pH} 5.0$, at $\mathrm{pH} 4.5(2.88 \mu \mathrm{g} / \mathrm{ml})$ and at $\mathrm{pH} 4.0(2.00 \mu \mathrm{g} / \mathrm{ml})$ respectively.

Table 2 Percentage occurrence of fungi species isolated from soil in Keffi

\begin{tabular}{|l|c|c|c|c|c|c|}
\hline & \multicolumn{6}{|c|}{ Locations } \\
\hline Fungi isolates & No sample & A & B & C & D & Occurrence (\%) \\
\hline Rhizopus oryzae & 4 & 2 & 1 & 0 & 1 & $4(100)$ \\
\hline Aspergillus carneus & 4 & 1 & 0 & 2 & 0 & $3(75.0)$ \\
\hline Aspergillus niger & 4 & 0 & 2 & 1 & 0 & $3(75.0)$ \\
\hline Aspergillus terreus & 4 & 1 & 1 & 1 & 1 & $4(100)$ \\
\hline Trichoderma viride & 4 & 1 & 0 & 0 & 1 & $2(50.0)$ \\
\hline Fusarium moniliforme & 4 & 0 & 1 & 0 & 1 & $2(50.0)$ \\
\hline
\end{tabular}

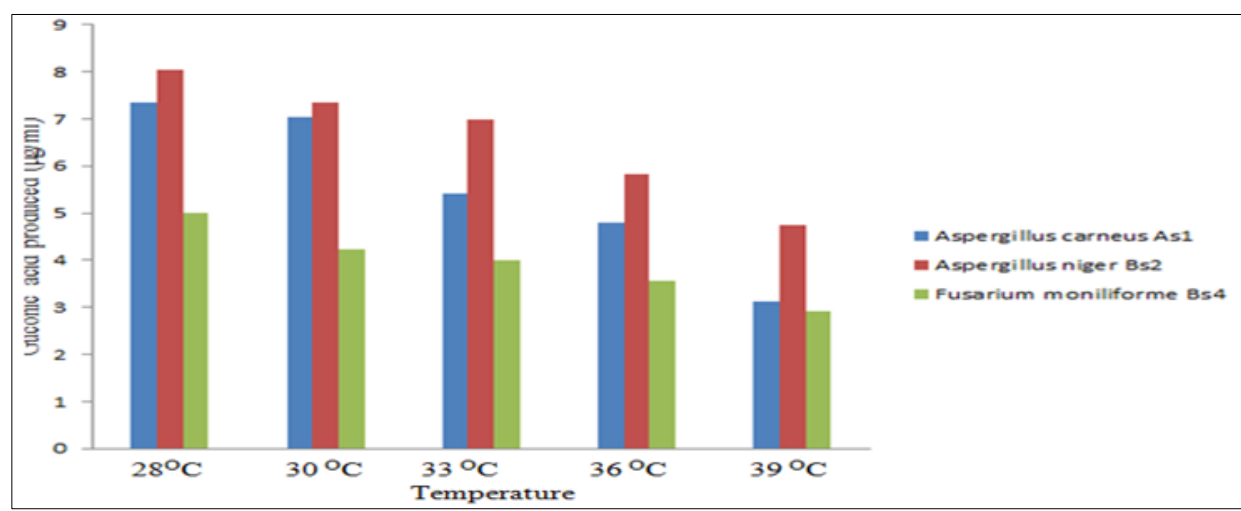

Figure 1 Effect of temperature on gluconic acid production by fungal isolates

Table 3 Screening for gluconic acid producing fungal isolated from soil

\begin{tabular}{|l|c|c|}
\hline Fungal & Sample codes & Gluconic acid producers \\
\hline Rhizopus oryzae & As2 & - \\
\hline Rhizopus oryzae & As2 & - \\
\hline Rhizopus oryzae & Bs3 & - \\
\hline Rhizopus oryzae & Ds1 & - \\
\hline
\end{tabular}




\begin{tabular}{|l|l|l|}
\hline Aspergillus carneus & As1 & + \\
\hline Aspergillus carneus & Cs1 & + \\
\hline Aspergillus carneus & Cs2 & + \\
\hline Aspergillus niger & Bs1 & + \\
\hline Aspergillus niger & Bs2 & + \\
\hline Aspergillus niger & Cs4 & + \\
\hline Aspergillus terreus & As4 & - \\
\hline Aspergillus terreus & Bs3 & - \\
\hline Aspergillus terreus & Cs3 & - \\
\hline Aspergillus terreus & Ds2 & - \\
\hline Trichoderma viride & As4 & - \\
\hline Trichoderma viride & Ds4 & - \\
\hline Fusarium moniliforme & Bs4 & + \\
\hline Fusarium moniliforme & Ds1 & + \\
\hline
\end{tabular}

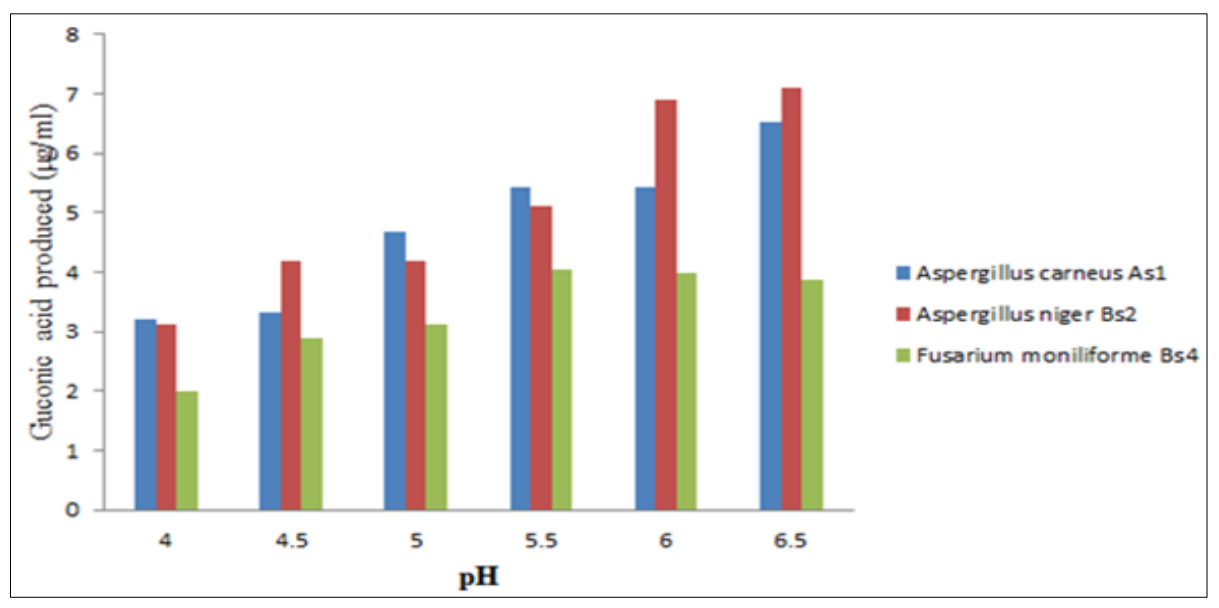

Figure 2 Effect of $\mathrm{pH}$ on gluconic acid production by fungal isolates

The effect of substrate concentration on gluconic acid production is as given in Figure 3. The highest gluconic acid produced at different substrate concentration was by Aspergillus niger Bs2 at substrate concentration of 25\% (6.98 $\mu \mathrm{g} / \mathrm{ml})$ followed by at substrate concentration of $20 \%(5.42 \mu \mathrm{g} / \mathrm{ml}), 15 \%$ substrate concentration $(5.09 \mu \mathrm{g} / \mathrm{ml}), 10 \%$ substrate concentration $(3.24 \mu \mathrm{g} / \mathrm{ml})$ and the least was at $5 \%$ substrate concentration $(1.75 \mu \mathrm{g} / \mathrm{ml})$. Aspergillus carneus As1 produced highest at substrate concentration of $20 \%$ with the yield of $5.51 \mu \mathrm{g} / \mathrm{ml}$ followed by $25 \%$ substrate concentration with $4.62 \mu \mathrm{g} / \mathrm{ml}$, at $15 \%$ substrate concentration it produces $4.01 \mu \mathrm{g} / \mathrm{ml}, 10 \%$ substrate concentration it produced $3.11 \mu \mathrm{g} / \mathrm{ml}$ and at $5 \%$ substrate concentration it produced $1.19 \mu \mathrm{g} / \mathrm{ml}$. Fusarium moniliforme Bs4 produced highest at substrate concentration of $20 \%$ with the yield of $4.27 \mu \mathrm{g} / \mathrm{ml}$ followed by $15 \%$ substrate concentration with $4.22 \mu \mathrm{g} / \mathrm{ml}$, at $25 \%$ substrate concentration it produces $3.03 \mu \mathrm{g} / \mathrm{ml}$, at $10 \%$ substrate concentration it produced 2.11 $\mu \mathrm{g} / \mathrm{ml}$ and at $5 \%$ substrate concentration it produced $1.05 \mu \mathrm{g} / \mathrm{ml}$ respectively.

The effect of fermentation time on gluconic acid production by fungal isolates is as given in Figure 4. highest gluconic acid was produced by Aspergillus niger Bs2 after 144hrs with $5.02 \mu \mathrm{g} / \mathrm{ml}$ followed by after $168 \mathrm{hrs} \mathrm{with} 4.88 \mu \mathrm{g} / \mathrm{ml}$, $120 \mathrm{hrs}$ with $4.14 \mu \mathrm{g} / \mathrm{ml}$, $96 \mathrm{hrs}$ with $4.01 \mu \mathrm{g} / \mathrm{ml}, 192 \mathrm{hrs}$ with $4.00 \mu \mathrm{g} / \mathrm{ml}, 72 \mathrm{hrs}$ with $3.32 \mu \mathrm{g} / \mathrm{ml}$, $48 \mathrm{hrs}$ with $3.18 \mu \mathrm{g} / \mathrm{ml}$ and 24hrs with $2.00 \mu \mathrm{g} / \mathrm{ml}$. similarly Aspergillus carneus As1 produced highest gluconic acid after 144hrs with 4.50 $\mu \mathrm{g} / \mathrm{ml}$ followed by after $168 \mathrm{hrs}$ with $4.21 \mu \mathrm{g} / \mathrm{ml}, 120 \mathrm{hrs}$ with $4.12 \mu \mathrm{g} / \mathrm{ml}, 192 \mathrm{hrs}$ with $3.75 \mu \mathrm{g} / \mathrm{ml}$, 96hrs with 3.22 $\mu \mathrm{g} / \mathrm{ml}, 72 \mathrm{hrs}$ with $2.51 \mu \mathrm{g} / \mathrm{ml}, 48 \mathrm{hrs}$ with $2.49 \mu \mathrm{g} / \mathrm{ml}$ and $24 \mathrm{hrs}$ with $1.22 \mu \mathrm{g} / \mathrm{ml}$. whereas Fusarium moniliforme Bs4 
produced gluconic acid after $120 \mathrm{hrs}$ with $3.25 \mu \mathrm{g} / \mathrm{ml}$ followed by $144 \mathrm{hrs}$ with $3.08 \mu \mathrm{g} / \mathrm{ml}, 168 \mathrm{hrs}$ with $2.98 \mu \mathrm{g} / \mathrm{ml}$, $192 \mathrm{hrs}$ with $2.77 \mathrm{hrs}$, $96 \mathrm{hrs}$ with $2.01 \mu \mathrm{g} / \mathrm{ml}, 72 \mathrm{hrs}$ with $1.97 \mu \mathrm{g} / \mathrm{ml}, 48 \mathrm{hrs}$ with $1.68 \mu \mathrm{g} / \mathrm{ml}$ and $24 \mathrm{hrs}$ with $1.10 \mu \mathrm{g} / \mathrm{ml}$ respectively.

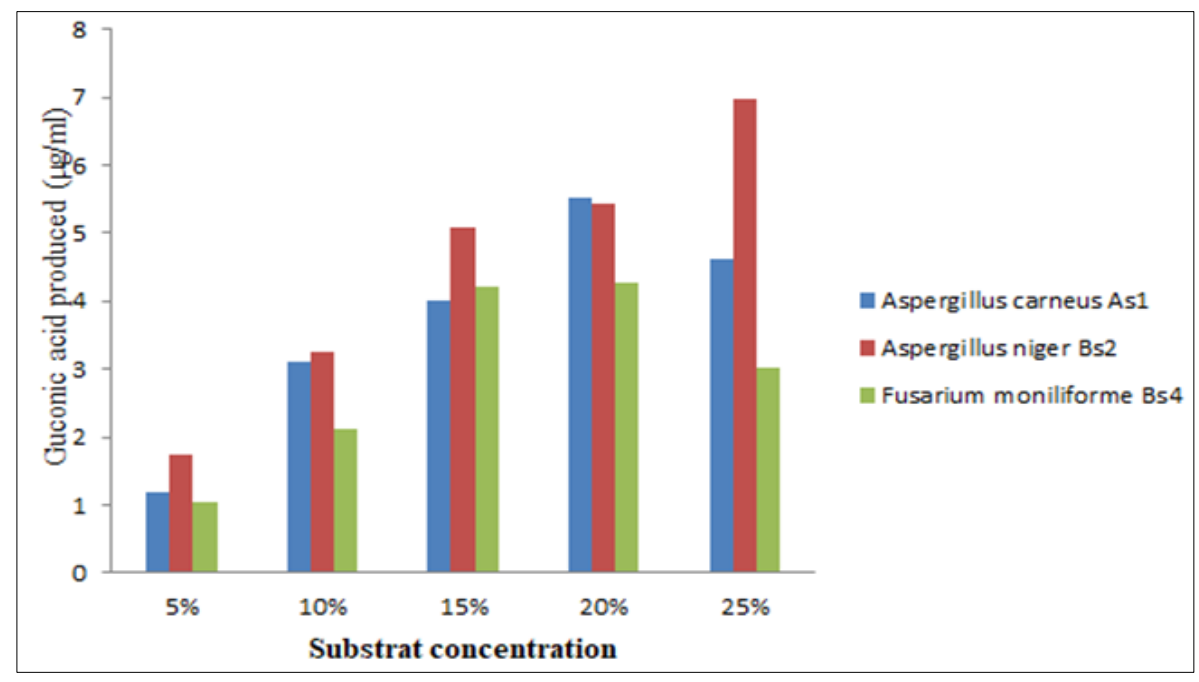

Figure 3 Effect of substrate concentration on gluconic acid production by fungal isolates

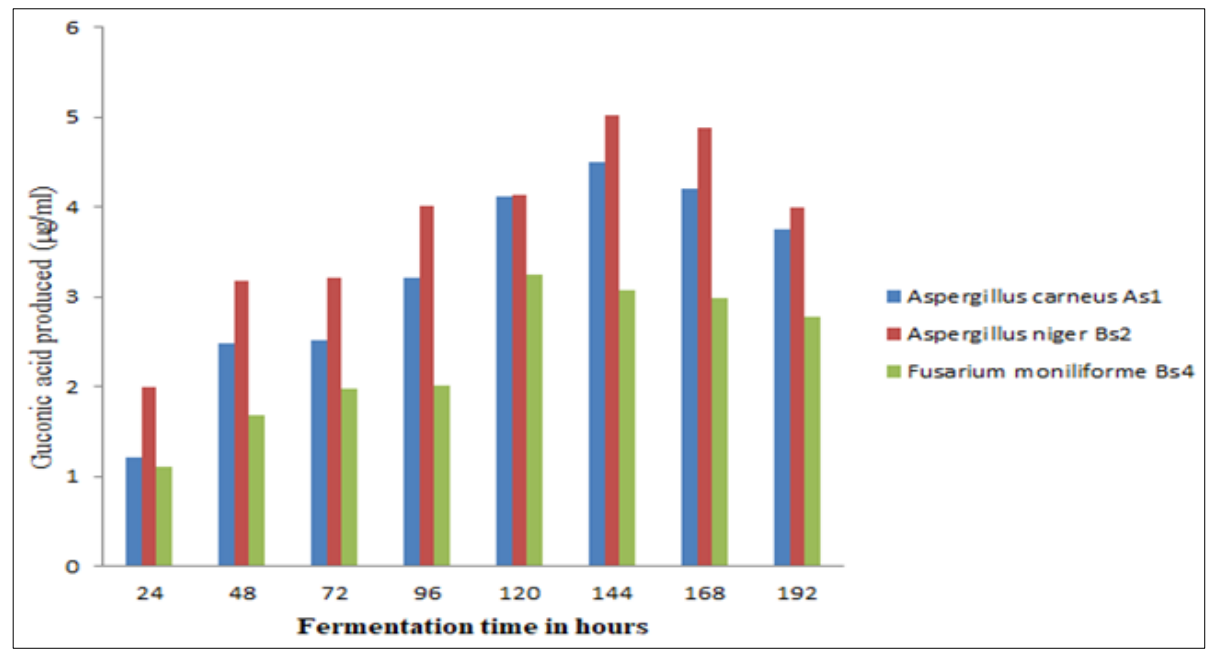

Figure 4 Effect of time on gluconic acid production by fungal isolates

\section{Discussion}

In this study the occurrence of fungal from different location was high which showed a percentage ranging from $25.0 \%$ - 75.0\% from all the location. This is not as expected because fungi play an important role in breaking down most of both organic and inorganic waste in the environment and is similar to study earlier reported by Nimkar et al. [13] and Suganthi, et al. [14].

The ability of gluconic acid production in various amount demonstrated by different fungal isolated from soil in different location in this study was in agreement with work reported by Shindia et al. [1] on the ability of gluconic acid production by some local fungi which are known to utilized various substrate and release different secondary metabolites.

In this study that highest gluconic acid production was at temperature of $28^{\circ} \mathrm{C}$ by both Aspergillus species (Aspergillus niger and Aspergillus carneus) while Fusarium moniliforme produced highest gluconic acid at temperature of $30^{\circ} \mathrm{C}$ respectively. This showed that fermentation temperature plays an important role in production of gluconic acid when using different microorganism in bioacid production, which influence the growth and accumulation of the bioacid by the microorganism. This is similar to work early reported by Cheema et al. [14] who reported high gluconic acid 
production at $28^{\circ} \mathrm{C}$ by Aspergillus niger but in disagreement with work reported by Shindia et al. [1] who reported high gluconic acid production by Fusarium moniliforme at temperature of $28^{\circ} \mathrm{C}$.

The effect of $\mathrm{pH}$ is an important parameter in production of organic acid or bioacid using fungal or any other microorganism. In this study high gluconic acid was obtain at pH 6.5 both Aspergillus species (Aspergillus niger and Aspergillus carneus) and pH 6.0 for Fusarium moniliforme this is similar to study reported by Dowdells et al. [15] and Capuder et al. [16]. The realization of gluconic acid production from glucose by fungal species at relatively high $\mathrm{pH}$ in the fermentation indicates innovative routes to glucose use for the production of lovastatin and other secondary metabolites without further genetic manipulation of industrial strains, but the production of high concentrations of gluconic acid would disrupt $\mathrm{pH}$ regulation in the fermentation and introduce high concentrations of osmotically active solutes especially if the accumulated acid (causing base addition) was later utilized as a carbon source (Dowdells et al. [15].

The effect of substrate concentration as observed in this study showed that it is an important parameter in production of gluconic acid. The availability of substrate enhanced the accumulation of this important organic acid.it was observed that at $25 \%$ concentration and $20 \%$ concentration by the fungal species used in this study which is agreement with work reported by El-Enshasy [8]. Non availability of fermentation substrate will lead in depletion or reused of acid accumulated as source of carbon by the fungal and minimize gluconate formation in secondary product processes, therefore, high concentrations of glucose must be avoided.

\section{Conclusion}

From results obtain from this study the production of gluconic acid by fungal species isolated from soil in different location in Keffi showed the isolation of different fungal from soil namely Rhizopus oryzae, Aspergillus carneus, Aspergillus niger, Aspergillus terreus, Trichoderma viride and Fusarium moniliforme. These fungal isolates showed varying ability in gluconic acid production base on different fermentation parameter studied and Aspergillus carneus, Aspergillus and Fusarium moniliforme showed to be a good industrial strain in production of gluconic acid.

\section{Compliance with ethical standards}

\section{Acknowledgments}

We wish to express our appreciation to the Department of Microbiology Nasarawa state University Keffi for providing the Laboratory space used to carry out the analysis for this study.

\section{Disclosure of conflict of interest}

The authors declare that they have no conflict of interest or personal interest.

\section{References}

[1] Shindia AA, El-Sherbeny GA, El-Esawy AE, Sheriff YMMM. Production of Gluconic Acid by Some Local Fungi. Mycobiology. 2006; 34(1): 22-29.

[2] El-Enshasy HA. Production of gluconic acid by free and immobilized cells of recombinant Aspergillus Niger in batch cultures. Egypt Journal of Biotechnology. 2003; 13:187-201.

[3] Kundu PN, Das A. Utilization of cheap carbohydrate sources for production of calcium gluconate by Penicillim funiculosum mutant MN-238. Ind J Exp Biol. 1984; 22: 279-281.

[4] Lee HW, Pan JG, Lebeault JM. Calcium gluconate form glucose substrate. Appl Microbial Biotechol. 1988; 49: 915.

[5] Spankpal NV, Kulkarni BD. Optimization of fermentation conditions for gluconic acid production using Aspergillus Niger immobilized on cellulose micro-fabrics. Process Biochem. 2002; 37: 1345-1350.

[6] Spankpal NV, Cheema JJS, Jambe SS, Julkarni BD. An artificial intelligence tool for bioprocesses monitoring: Application to continuous production of gluconic acid by immobilized Aspergillus Niger. Biotechnol Lett. 2001; 23: 911-916. 
[7] Makut MD, Ade-Ibijola OB. Citric acid producing fungi found in the soil environment of Keffi Metropolis, Nasarawa State. International Resources Journal of microboiolgy. 2012; 3(7): 240-245.

[8] El-Enshasy HA. Production of gluconic acid by immobilized cells of recombinant Aspergillus niger in continues cultures. Egypt J Biotechnol. 2014; 15: 17-24.

[9] Ekeleme IK, Makut MD, Adoga MP, Tsaku PA, Nkene IH, Oti VB. Production of Citric Acid by Trichoderma viride Isolated from Soil in Keffi, Nigeria Using Glucose Enhanced Substrates, South Asian Journal of Research in Microbiology. 2018; 1(1): 1-6.

[10] Ekeleme IK, Makut MD, Owuna JE, Nkene IH, Alfa FU, SO Obiekezie. Citric Acid Production using Induced Mutant Aspergillus Niger and Aspergillus awamori Isolated from Soil. South Asian Research Journal of Natural Products. 2021; 4(3): 59-67.

[11] Akalin AS, Gonc S, Akbas Y. Variation in organic acids content during ripening of pickled white cheese. Journal of Dairy Sciences. 2002; 85: 1670-76.

[12] Si S, Si T, Liu Z, Zhag H, Ang EL, Zhao H. Metabolic Engineering of Synergistic Pathway for n-butanol Production in Saccharomyces cerevisiae. Scientific Reports. 2016; 6(25675): 1-10.

[13] Nimkar MD, Deogade NG, Kawale M. Production of alpha-amylase from Bacillus subtilis and Aspergillus Niger using different agro waste by solid state fermentation, Asiatic Journal of Biotechnology. Res. 2010; 1: 23-28.

[14] Suganthi RJF, Benazir R, Santhi V, Ramesh Kumar A, Hari N, Meenakshi KA, Nidhiya G, Kavitha R, Lakshmi. Amylase production by Aspergillus Niger under solid state fermentation using agricultural wastes. International Journal of Engineering Science Technology. 2011;3(2): 1756-1763.

[15] Cheema JJ, Sankpal NV, Tambe SS, Kulkarni BD. Genetic programming assisted stochastic optimization strategies for optimization of glucose to gluconic acid fermentation. Biotechnology Prog. 2002; 18: 1356.

[16] Dowdells C, Jones RL, Mattey M, Benčina M, Legiša M, Mousdale DM. Gluconic acid production by Aspergillus terreus. Society of applied microbiology. 2010; 4(5): 114-124.

[17] Capuder M, Šolar T, Benčina M, Legiša M. Highly active, citrate inhibition resistant form of Aspergillus Niger 6phosphofructo-1-kinase encoded by a modified pfkA gene. Journal of Biotechnology. 2009; 144: 51. 